Info Artikel:

\title{
KEJAHATAN BERTOPENG AGAMA: SEBUAH TINJAUAN SOSIOLOGI AGAMA
}

\author{
Saiful Anwar \\ IAIN Syaikh Abdurrahman Siddik Bangka Belitung \\ sayaanwar5@gmail.com
}

\begin{abstract}
Religion wherever it is, always being replaced in high state of human life. Religion, as the source of all sources, is used as a tool to role human either vertically or horizontally. Karl Marx said that religion is a blessed heart against a cold and heartless world. Religion is a human medium to have more sympathy and empathy for others to live a warmer and friendlier life in peace. However, it cannot be denied that religion was once a sword used to commit genocide or mass annihilation by a group of humans against other human groups either directly or indirectly. Crusades, the middle-east war that is still going on are two examples of the dark events of human destruction wrapped by religion. Terrorism that occurs today is a deviation that is also wrapped by religion. These crimes are the result of a distortion of religious doctrine. Not only are physical destructive but also psychological and materialistic crimes. Cases of misappropriation of funds like the First Travel case are one of them. This paper will attempt to explore the phenomenon of crime in the name of Islam that happened lately in Indonesia. This paper will explore the phenomenon with a philosophical and social approach.
\end{abstract}

\begin{abstract}
Abstrak
Agama dimanapun keberadaanya, selalu memiliki kedudukan yang tinggi dalam kehidupan manusia. Agama merupakan sumber segala sumber yang dijadikan alat untuk mengatur perilaku manusia baik secara vertikal maupun horizontal. Mengutip pernyataan Karl Marx bahwa agama merupakan hati yang berbela rasa terhadap dunia yang dingin dan tanpa hati. Agama merupakan media manusia untuk lebih memiliki rasa simpati dan empati terhadap sesama agar hidup lebih hangat dan bersahabat dalam kedamaian. Namun, tidak bisa dipungkiri bahwa agama pernah menjadi sebuah pedang yang digunakan untuk melakukan genosida atau pemusnahan masal oleh sekelompok manusia terhadap kelompok manusia lainnya baik secara langsung maupun tidak langsung. Perang salib, perang timur tengah
\end{abstract}


yang saat ini masih terjadi adalah dua contoh peristiwa kelam pemusnahan manusia yang dibalut oleh agama. Terorisme yang terjadi saat ini merupakan penyimpangan yang juga dibungkus oleh agama. Kejahatan-kejahatan yang terjadi tersebut adalah hasil distorsi dari doktrin agama. Tidak hanya kejahatan yang destruktif secara fisik namun juga psikologis dan materialistis. Kasus penyelewengan dana seperti kasus First Travel adalah salah satunya. Tulisan ini akan berusaha mengupas fenomena-fenomena kejahatan yang mengatasnamakan agama Islam yang terjadi akhir-akhir ini di Indonesia. Tulisan ini akan menggali fenomena tersebut dengan pendekatan filsafat dan sosial.

Keywords: Crime, Religion, Islam, Indonesian

\section{PENDAHULUAN}

Akhir-akhir ini banyak terjadi kejahatan yang ditimbulkan atas nama agama, agama Islam khususnya. Islam yang turun ke dunia ini sebagai agama rahmat, agama yang membawa nila-nilai, ajaran dan ajakan kedamaian bagi seluruh umat manusia. Namun nilai-nilai itu seolah-olah mengalami mal-fungsinya karena perilaku sebagian kecil pemeluknya. Terorisme merupakan kejahatan yang telah jamak diketahui sebagai penyimpangan ajaran agama, yang paling banyak adalah penyimpangan ajaran agama Islam. Lalu, di Indonesia baru-baru ini terjadi konflik politik antara kelompok yang mengatasnamakan agama Islam untuk menjegal seorang pimpinan yang beragama selain Islam. Konflik tersebut sempat membuat was-was seluruh elemen masyarakat di Indonesia karena dikhawatirkan dapat berkembang menjadi konflik SARA yang ujungnya akan membawa kepada perang saudara.

Kejadian-kejadian tersebut juga dipandang dapat menjadi pemicu keretakan hubungan yang selama ini sudah terjalin dengan baik, toleransi antara pemeluk agama Islam dengan umat lainnya di Indonesia. Lebih parah lagi, konflik tersebut sering dimanfaatkan oleh pemangku kepentingan sebagai kuda pacu untuk mewujudkan ambisinya tanpa memikirkan imbasnya secara luas. Sungguh disayangkan agama dijadikan sebagai topeng orang-orang yang haus kekuasaan dan sumber daya alam.

Kejahatan adalah peristiwa sosiologis dan politik yang bersifat universal yang dapat berlangsung mulai dari level individual, kolektif, institusi, hingga sistem secara keseluruhan. Dari aspek sosiologis, agama seringkali dijadikan sebagai identitas sosial suatu masyarakat yang dapat memainkan peranan dalam kerasnya konflik-konflik sosial. Apabila agama dijadikan sebagai identitas sosial, maka mau tidak mau konflik-konflik sosial terjadi. Dari segi politik, pemangku kepentingkan seringkali membenturkan antara doktrin agama yang satu dengan doktrin agama yang lain atau pemeluk agama yang satu dengan agama yang lain demi mencapai tujuan politiknya. Hal ini sering menjadi pemicu gesekan-gesekan dan peperangan baik secara verbal maupun secara fisik antar umat beragama.

Kejahatan atas nama agama bisa berlangsung secara horisontal pada masing-masing level, tetapi bisa juga berlangsung secara vertikal atau kombinasi di antara keduanya. Kejahatan juga bisa berlangsung secara terbuka, tetapi juga bisa bersifat tertutup, sebagaimana diekspresikan dengan sangat baik dalam kejahatan domestik yang umumnya menempatkan kaum perempuan dan anak-anak sebagai objek dan korban kejahatan. Cornelis Lay, sebagaimana dikutip Alam dan 
Amir Ilya ${ }^{1}$ berpendapat bahwa raut ekspresi kejahatan atau kekerasan sangat bervariasi, mulai dari kekerasan yang bersifat simbolik hingga pada kekerasan fisik; dari kekerasan verbal hingga peperangan antar bangsa atau negara.

Metode yang dilibatkan dalam kekerasan juga sangat bervariasi. Akan tetapi di antara variasi metode yang dipakai, terdapat kesamaan watak yakni eksploitasi energi anarkis baik yang inherent dalam nature manusia sebagai "makhluk", maupun energi anarkis yang merupakan produk karya peradaban manusia, seperti senjata dan sistem persenjataan, misalnya. Daya dan wilayah jangkauan destruksi dari kekerasan, juga bervariasi, mulai dari kehancuran yang bersifat total hingga pada kehancuran terbatas, mulai dari kehancuran fisik hingga pada kehancuran yang bersifat psikis.

Mengacu pada paragraf pertama, bahwa agama sebenarnya mengajarkan nilai-nilai kedamaian, demi melihat realitas sejarah peperangan dan kejahatan yang tidak sedikit berangkat dari semangat keagamaan, maka maklum jika kemudian muncul pertanyaan apakah agama itu berbahaya? Benarkah demikian? Lebih khusus lagi, apakah ajaran agama Islam itu berbahaya, mengajarkan kekerasan dan intoleran? Apakah agama Islam lebih banyak jahatnya daripada kebaikannya? Apakah agama Islam merupakan sesuatu yang harus ditakuti dan dilawan karena merusak dan menjerumuskan generasi kepada perilaku terorisme dan kejahatan?

Pertanyaan-pertanyaan tersebut membutuhkan jawaban yang rasional, yang dapat diterima baik oleh pemeluknya maupun umat lain sehingga agama Islam tidak kehilangan jati dirinya dan tidak dianggap sebagai agama penghasil teroris dan kejahatan. Umat Islam harus segara memberikan jawaban agar mereka yang tidak percaya secara berangsur-angsur menyadari bahwa bukan ajaran Islam yang keliru namun pemahan sebagian pemeluknya yang keliru.

Dalam perspektif penulis, agama Islam maupun agama lain diturunkan ke dunia ini adalah sebagai pedoman bagi umatnya untuk berbuat lebih baik. Ajaran agama secara umum lebih banyak mengatur norma-norma yang mengarahkan manusia untuk berbuat kebaikan. Seorang manusia tentu akan cenderung lebih buruk jika ia tanpa berpedoman dengan agama. Tentu saja setiap agama itu berbeda-beda, namun pada intinya, agama memberikan kesempatan bagi umatnya untuk berbuat kebaikan dan memiliki harapan yang lebih baik akan masa depannya.

\section{PEMBAHASAN}

\section{Agama}

Agama dan kejahatan merupakan dua istilah yang sangat bertentangan. Agama identik dengan norma-norma kehidupan manusia yang bermoral dan berintelektual. Sedangkan kejahatan merupakan istilah yang dipakai untuk menggambarkan perilaku yang jauh dari nilai moral dan intelektual. Syahrudin mengutip kamus Oxford, agama atau religion didefinisikan sebagai berikut: "The belief in and worship of a superhuman controlling power, especially a personal God or gods" "2. Keyakinan dan pemujaan atas dzat yang mengontrol kekuatan, yang dinamakan Tuhan. Dalam kamus umum bahasa Indonesia, agama berarti segenap kepercayaan (kepada Tuhan, Dewa dsb) serta dengan ajaran kebaktian dan kewajiban- kewajiban yang bertalian dengan kepercayaan itu.

\footnotetext{
${ }^{1}$ Alam A.S \& Amir Ilya, Pengantar Kriminologi, ( Makasar: Pustaka Refleksi, 2010), hlm. 77

2 Syahruddin, Kejahatan dalam Masyarakat dan Upaya Penanggulangannya, ( Fakultas Hukum Universitas Sumatera Utara, 2003) hlm.181
} 
Menurut Poerwadarminta, Agama dari sudut bahasa (etimologi) berarti peraturan- peraturan tradisional, ajaran- ajaran, kumpulan- kumpulan hukum yang turun temurun dan ditentukan oleh adat kebiasaan. Agama asalnya terdiri dari dua suku kata, yaitu $a$ berarti tidak dan gama berarti kacau. ${ }^{3}$ Jadi agama mempunyai arti tidak kacau. Arti ini dapat dipahami dengan melihat hasil yang diberikan oleh peraturan- peraturan agama kepada moral atau materiil pemeluknya, seperti yang diakui oleh orang yang mempunyai pengetahuan.

Dalam bahasa Arab, agama berasal dari kata ad-din, dalam bahasa Latin dari kata religi, dan dalam bahasa Inggris dari kata religion. Religion dalam bahasa Inggris (dinun) dalam bahasa Arab memiliki arti sebagai berikut: ${ }^{4}$

a. Organisasi masyarakat yang menyusun pelaksanaan segolongan manusia yang periodik, pelaksanaan ibadah, memiliki kepercayaan, yaitu kesempurnaan zat yang mutlak, mempercayai hubungan manusia dengan kekuatan rohani yang leibih mulia dari pada ia sendiri. Rohani itu terdapat pada seluruh alam ini, baik dipandang esa, yaitu Tuhan atau dipandang berbilang- bilang.

b. Keadaan tertentu pada seseorang, terdiri dari perasaan halus dan kepercayaan, termasuk pekerjaan biasa yang digantungkan dengan Allah SWT.

c. Penghormatan dengan khusuk terhadap sesuatu perundang- undangan atau adat istiadat dan perasaan. (Abdullah, 2004:3) Agama semakna juga dengan kata addin (bahasa Arab) yang berarti cara, adat kebiasaan, peraturan, undang- undang, taat dan patuh, mengesakan Tuhan

Hampir semua pengertian agama setuju bahwa agama merupakan ajaran yang di dalamnya terdapat peraturan-peraturan atau hukum yang harus dipatuhi panganut agama yang bersangkutan. Selanjutnya agama juga menguasai diri seseorang dan membuat dia tunduk dan patuh kepada Tuhan dengan menjalankan ajaran- ajaran agama. Agama lebih lanjut membawa utang yang harus dibayar oleh penganutnya. Paham kewajiban dan kepatuhan ini selanjutnya membawa kepada timbulnya paham balasan. Orang yang menjalankan kewajiban dan patuh kepada perintah agama akan mendapat balasan yang baik dari Tuhan, Sedangkan orang yang tidak menjalankan kewajiban dan ingkar terhadap perintah Tuhan akan mendapat balasan yang menyedihkan.

Adapun kata religi berasal dari bahasa Latin yaitu berasal dari kata relegere yang mengandung arti yang mengumpulkan dan membaca. Pengertian demikian itu juga sejalan dengan isi agama yang mengandung kumpulan cara- cara mengabdi kepada Tuhan yang terkumpul dalam kitab suci yang harus dibaca. Ada yang berpendapat kata itu berasal dari kata religare yang berarti mengikat. Ajaran- ajaran agama memang mempunyai sifat mengikat bagi manusia. Dalam agama selanjutnya terdapat pula ikatan antara roh manusia dengan Tuhan, dan agama lebih lanjut lagi memang mengikat manusia dengan Tuhan. ${ }^{5}$

Harun Nasution dalam Abuddin $\mathrm{Nata}^{6}$ memberikan definisi agama sebagai berikut 1). Pengakuan terhadap adanya hubungan manusia dengan kekuatan gaib yang harus di dipatuhi; 2). Pengakuan terhadap adanya kekuatan gaib yang menguasai manusia; 3). Mengikatkan diri pada suatu bentuk hidup yang mangandung pengakuan pada suatu sumber

\footnotetext{
${ }^{3}$ WJS. Poerwadarminta, Kamus Umum Bahasa Indonesia, (Jakarta: Balai Pustaka, 1982),hlm. 18

${ }^{4}$ M.Y. Abdullah, Studi Islam Kontemporer, (Pekan Baru: Amzah, 2004), hlm. 2

${ }^{5}$ Abuddin Nata, Metodologi Studi Islam, (Jakarta: Raja Grafindo Persada, 2011), hlm. 10

${ }^{6}$ Ibid, hlm. 14
} 
yang berada di luar diri manusia yang mempengaruhi perbuatan- perbuatan manusia; 4). Kepercayaan pada suatu kekuatan gaib yang menimbulkan cara hidup tertentu; 5). Suatu sistem tingkah laku (code of conduct) yang berasal dari kekuatan gaib; 6). Pengakuan terhadap adanya kewajiban- kewajiban yang diyakini bersumber pada suatu kekuatan gaib; 7). Pemujaan terhadap kekuatan gaib yang timbul dari perasaan lemah dan perasaan takut terhadap kekuatan misterius nyang terdapat dalam alam sekitar manusia; 8). Ajaran yang diwahyukan Tuhan kepada manusia melalui seorang rasul.

Dari beberapa definisi tersebut di atas, Abudin Nata ${ }^{7}$ memberikan kesimpulan bahwa ada empat unsur yang menjadi karakteristik agama sebagai berikut: Pertama, unsur kepercayaan terhadap kekuatan gaib. Kekuatan gaib tersebut dapat mengambil bentuk yang bermacam- macam. Dalam agama primitif kekuatan gaib tersebut dapat mengambil bentuk benda- benda yang memiliki kekuatan misterius (sakti), ruh atau jiwa yang terdapat pada benda- benda yang memiliki kekuatan misterius; dewa-dewa dan Tuhan atau allah dalam istilah yang lebih khusus dalam agama Islam. Kepercayaan pada adanya Tuhan adalah dasar yang utama sekali dalam paham keagamaan. Tiap-tiap agama kecuali Budhisme yang asli dan beberapa agama lain berdasar atas kepercayaan pada sesuatu kekuatan gaib dan cara hidup tiap- tiap manusia yang percaya pada agama di dunia ini amat rapat hubungannya dengan kepercayaan tersebut. Kedua, unsur kepercayaan bahwa kebahagiaan dan kesejahteraan hidup di dunia ini dan di akhirat nanti tergantung pada adanya hubungan yang baik itu, kesejahteraan dan kebahagiaan yang dicari akan hilang pula. Hubungan baik ini selanjutnya diwujudkan dalam bentuk peribadatan, selalu mengingat-Nya, melaksanakan segala perintahNya, dan menjauhi larangan-Nya. Ketiga, unsur respon yang bersifat emosional dari manusia. respon tersebut dapat mengambil bentuk rasa takut, seperti yang terdapat pada agama primitif, atau perasaan cinta seperti yang terdapat pada agama- agama monoteisme. Selanjutnya respon tersebut dapat pula mengambil bentuk penyembahan seperti yang terdapat pada agamaagama monoteisme dan pada akhirnya respon tersebut mengambil bentuk dan cara hidup tertentu bagi masyarakat ang bersangkutan. Keempat, unsur paham adanya yang kudus (sacred) dan suci, dalam bentuk kekuatan gaib, dalam bentuk kitab suci yang mengandung ajaran- ajaran agama yang bersangkutan, tempat- tempat tertentu, peralatan untuk menyelenggarakan upacara, dan sebagainya.

\section{Kejahatan}

Kejahatan merupakan tindakan destruktif yang dapat dilakukan oleh siapa saja dan di mana saja selagi ada kesempatan dan niat, baik secara sadar maupun tidak sadar, spontanitas maupun insidental. Definisi kejahatan menurut Kartono, sebagaimana dikutip Alam, A.S ${ }^{8}$, kejahatan secara yuridis formal, kejahatan adalah bentuk tingkah laku yang bertentangan dengan moral kemanusiaan (immoril), merupakan masyarakat, asosial sifatnya dan melanggar hukum serta undang-undang pidana. secara sosiologis, kejahatan adalah semua ucapan, perbuatan dan tingkah laku yang secara ekonomis, politis dan sosial psikologis sangat merugikan masyarakat, melanggar norma-norma susila dan menyerang keselamatan warga masyarakat (baik yang telah tercantum dalam undang-undang pidana).

\footnotetext{
${ }^{7}$ Ibid. hlm. 15

${ }^{8}$ A.S Alam, A.S, Kejahatan dan Sistem Pemidanaan, (Ujung Pandang: Fakultas Hukum, UNHAS, 1985), hlm. 3
} 
Kejahatan secara umum dikatakan sebagai aktivitas penyimpangan terhadap normanorma yang berlaku dalam masyarakat. Semua orang yang memiliki perbuatan yang menyimpang dan tidak sesuai dengan norma dapat dikatakan sebagai orang yang jahat atau penjahat. Berikut ini definisi kejahatan menurut beberapa pakar yang dikutip Syahrudin. ${ }^{9}$ (2003: 2-3).

1. J.M. Bemmelem memandang kejahatan sebagai suatu tindakan anti sosial yang menimbulkan kerugian, ketidakpatutan dalam masyarakat, sehingga dalam masyarakat terdapat kegelisahan, dan untuk menentramkan masyarakat, negara harus menjatuhkan hukuman kepada penjahat.

2. M.A. Elliot mengatakan bahwa kejahatan adalah suatu problem dalam masyarakat modem atau tingkah laku yang gagal dan melanggar hukum dapat dijatuhi hukurnan penjara, hukuman mati dan hukuman denda dan seterusnya.

3. W.A. Bonger mengatakan bahwa kejahatan adalah perbuatan yang sangat anti sosial yang memperoleh tantangan dengan sadar dari negara berupa pemberian penderitaan.

4. Paul Moedikdo Moeliono kejahatan adalah perbuatan pelanggaran norma hukum yang ditafsirkan atau patut ditafsirkan masyarakat sebagai perbuatan yang merugikan, menjengkelkan sehingga tidak boleh dibiarkan (negara bertindak).

5. J.E. Sahetapy dan B. Marjono Reksodiputro dalam bukunya "Paradoks Dalam Kriminologi" menyatakan bahwa, kejahatan mengandung konotasi tertentu, merupakan suatu pengertian dan penamaan yang relatif, mengandung variabilitas dan dinamik serta bertalian dengan perbuatan atau tingkah laku (baik aktif maupun pasif), yang dinilai oleh sebagian mayoritas atau minoritas masyarakat sebagai suatu perbuatan anti sosial, suatu pemerkosaan terhadap skala nilai sosial dan atau perasaan hukum yang hidup dalam masyarakat sesuai dengan ruang dan waktu.

Ada beberapa penggolongan kejahatan yang didasarkan pada motif pelaku. Hal ini dikemukakan menurut pandangan Bonger sebagai berikut:

a. Kejahatan ekonomi (economic crimes), misalnya penyelundupan.

b. Kejahatan seksual (sexual crimes), misalnya perbuatan zina, Pasal 284 KUHP.

c. Kejahatan politik (politic crimes), misalnya pemberontakan Partai Komunis Indonesia, DI /TII dan lain sebagainya.

d. Kejahatan diri (moscellaneus crimes), misalnya penganiayaan yang motifnya dendam. $^{10}$

\footnotetext{
${ }^{9}$ Syahruddin, Kejahatan dalam Masyarakat ... hlm. 2-3

${ }^{10}$ A.S Alam, A.S, Kejahatan dan ... hlm. 5
} 


\section{Agama Islam}

Agama Islam adalah agama yang diturunkan oleh Allah Swt di wilayah Arab melalui seorang utusan yang bernama Muhammad atau Nabi Muhammad SAW. Kata Islam berasal dari bahasa Arab yang mempunyai arti agama Allah yang disyariatkan-Nya, sejak nabi Adam a.s hingga nabi Muhammad SAW, kepada umat manusia. Dasar-dasar agama Islam pada setiap zaman dan bagi setiap umat, tidak berubah, yaitu tetap mengajarkan agar umat manusia mengimani kepada Allah Yang Esa, kepada para Rasul-Nya dan sebagainya. Yang berubah hanyalah hal- hal yang berhubungan dengan syariatnya semata- mata. Syariat yang dibawa oleh Nabi Muhammad akan kekal, sampai hari Kiamat, karena telah Kebutuhan Manusia sesuai dengan perkembangan waktu (li kulli zaman) dan perkembangan tempat (li kulli makan). ${ }^{11}$

Kata Islam berasal dari kata "salam "yang artinya selamat, aman sentosa, sejahtera, yaitu aturan hidup yang dapat menyelamatkan manusia di dunia dan di akhirat. kata salam terdapat dalam al-Qur'an surat al- An'am ayat 54; surat al- A'raf ayat 46; dan surat an- Nahl ayat 32. Kata Islam juga berasal dari kata "aslama' yang artinya menyerah atau masuk Islam, yaitu agama yang mengajarkan penyerahan diri kepada Allah, tunduk dan taat kepada hukum Allah tanpa tawar menawar. Kata aslama terdapat dalam al-Qur'an surat al- Baqarah ayat 112; surat Ali Imran ayat 20 dan 83; surat an- Nisa' ayat 125; dan surat al-An'am ayat 14.

Kata Islam juga berasal dari kata "silmun” yang artinya keselamatan atau perdamaian, yakni agama yang mengajarkan hidup yang damai dan selamat. Kata silmun terdapat dalam surat al- Baqarah ayat 128; dan surat Muhammad ayat 35. Kata islam berasal dari kata “sulamun' yang artinya tangga, kesadaran, yaitu peraturan yang dapat mengangkat derajat kemanusiaan yang dapat mengantarkan orang kepada kehidupan yang bahagia. Abdullah mengutip Maulana Muhammad Ali dalam mendefinisikan Islam mengambil firman Allah surat al- Baqarah ayat $208^{12}$ yang artinya: "Hai orang-orang yang beriman, masuklah kamu ke dalam Islam keseluruhan, dan janganlah kamu turut langkah-langkah syaitan. Sesungguhnya syaitan itu musuh yang nyata bagimu." Dari pengertian ini, kata Islam dekat artinya dengan kata agama yang berarti menundukkan, patuh, utang, balasan dan kebiasaan. Senada dengan itu Nurcholis Madjid, dikutip Abdullah, ${ }^{13}$ berpendapat bahwa sikap pasrah kepada Tuhan adalah merupakan hakikat dari pengertian Islam.

Majelis Tarjih Muhammadiyah menyatakan bahwa agama Islam adalah agama yang dibawa oleh nabi Muhammad saw. Agama yang diturunkan tersebut dalam sunnah sahihah, berupa perintah- perintah dan larangan- larangan serta petunjuk kebaikan manusia. Abdullah juga mengutip M. Natsir yang berpendapat bahwa agama Islam adalah agama kepercayaan dan cara hidup yang mengandung faktor- faktor sebagai berikut: percaya adanya Tuhan, wahyu, hubungan antara Allah dengan manusia, roh manusia tidak berakhir, dan percaya bahwa keridhaan Allah adalah tujuan hidup. ${ }^{14}$

\footnotetext{
${ }^{11}$ Shodiq, Kamus Istilah Agama, (Jakarta: Sienttarama, 1988), hlm. 142

${ }^{12}$ M.Y. Abdullah, Studi Islam Kontemporer, (Pekan Baru: Amzah, 2004), hlm. 6

${ }^{13}$ Ibid, hlm. 7

${ }^{14}$ Ibid, hlm. 8
} 
Agama Islam adalah agama kepercayaan adanya Allah dan hukum yang diwahyukan kepada utusan- utusan-Nya untuk kebahagiaan hidup manusia. Sedangkan H. Endang Saefuddin Anshari, berpendapat bahwa agama Islam adalah agama yang berupa wahyu yang diturunkan oleh Allah kepada rasul-Nya untuk disampailkan kepada umat manusia sepanjang masa. ${ }^{15}$

Dapat disimpulkan bahwa pengertian agama Islam adalah suatu sistem keyakinan, penyembahan dan aturan- aturan Allah yang mengatur segala kehidupan manusia dalam berbagai hubungan; baik hubungan manusia dengan Allah, dengan sesama manusia dan dengan alam. Agama-agama Samawi dan Islam.

Islam adalah satu-satunya agama Samawi, sedangkan agama Nasrani dan agama Yahudi dalam bentuknya yang sekarang tidak dapat lagi disebut sebagai agama murni Samawi; palingpaling dapat disebut sebagai agama semi- Samawi atau agama semu- Samawi, karena kedua kitab suci kedua agama tersebut dalam bentuknya yang sekarang ini sudah sangat banyak diinterpolasi dengan pikiran- pikiran manusia. ${ }^{16}$ Bagaimana halnya dengan agama Nasrani dan agama Yahudi dalam bentuknya yang asli tentu saja adalah agama murni- Samawi. Oleh karena itu, kedua agama tersebut dalam bentuknya yang murni menurut pandangan al-Qur'an adalah Islam.

Bahkan menurut al- Qur'an, agama yang dianut oleh semua nabi- nabi Allah SWT itu seluruhnya adalah agama Islam. Dalam al-Qur'an antara lain dijelaskan oleh Allah SWT yang tercantum dalam surat al-Baqarah ayat 136 :

"Katakanlah (hai orangorang mukmin): "Kami beriman kepada Allah dan apa yang diturunkan kepada kami, dan apa yang diturunkan kepada Ibrahim, Isma'il, Ishaq, Ya'qub dan anak cucunya, dan apa yang diberikan kepada Musa dan Isa serta apa yang diberikan kepada nabi-nabi dari Tuhannya. kami tidak membeda-bedakan seorangpun diantara mereka dan kami Hanya tunduk patuh kepada-Nya".

Terdapat juga dalam surat Yunus ayat 72: Nabi Nuh A.S berkata” Aku disuruh supaya Aku termasuk golongan Muslimin yaitu orang-orang yang berserah diri (kepada-Nya)". Di dalam surat al-Baqarah ayat 130-131 tercatat mengenai Nabi Ibrahim A.S sebagai berikut; "Dan tidak ada yang benci kepada agama Ibrahim, melainkan orang yang memperbodoh dirinya sendiri, dan sungguh Kami telah memilihnya di dunia dan sesungguhnya dia di akhirat benar-benar termasuk orang-orang yang saleh. Ketika Tuhannya berfirman kepadanya: "Tunduk patuhlah!" Ibrahim menjawab: "Aku tunduk patuh kepada Tuhan semesta alam".

Dikisahkan juga dalam surat Yusuf ayat 101 bahwa: "Nabi Yusuf berkata kepada Rabbnya (Ya Tuhan) Pencipta langit dan bumi. Engkaulah Pelindungku di dunia dan di akhirat, wafatkanlah aku dalam keadaan Islam dan gabungkanlah aku dengan orang-orang yang saleh. Dalam surat Yunus ayat 84, Berkata Musa: "Hai kaumku, jika kamu beriman kepada Allah, maka bertawakkallah kepada-Nya saja, jika kamu benar-benar orang yang berserah diri."

Al-Qur'an mencatat dalam surat Ali- Imran ayat 52, tentang nabi Isa a.s. "Maka tatkala Isa mengetahui keingkaran mereka (Bani lsrail) berkatalah dia: "Siapakah yang akan menjadi

\footnotetext{
${ }^{15}$ H. Endang Saifuddin Anshari, M.A, Wawasan Islam; Pokok-pokok pikiran tentang paradigma dan sistem Islam, (Gema Insani Press:Jakarta, 2005) hlm. 31

${ }^{16}$ H. Endang Saifuddin Anshari, M.A, Wawasan Islam...hlm. 67
} 
penolong-penolongku untuk (menegakkan agama) Allah?" para hawariyyin (sahabat-sahabat setia) menjawab: "Kamilah penolong-penolong (agama) Allah, kami beriman kepada Allah; dan saksikanlah bahwa sesungguhnya kami adalah orang-orang yang berserah diri (muslimun)." Selanjutnya Allah SWT mengutus seorang rasul-Nya, penutup para rasul Allah yang terdahulu itu.

Firman Allah dalam surat an- Nisa' ayat 163-165, bahwa: "Sesungguhnya Kami telah memberikan wahyu kepadamu sebagaimana Kami telah memberikan wahyu kepada Nuh dan nabinabi yang kemudiannya, dan Kami telah memberikan wahyu (pula) kepada Ibrahim, Isma'il, Ishak, Ya'qub dan anak cucunya, Isa, Ayyub, Yunus, Harun dan Sulaiman. dan kami berikan Zabur kepada Daud. Dan (Kami telah mengutus) rasul-rasul yang sungguh telah Kami kisahkan tentang mereka kepadamu dahulu, dan rasul-rasul yang tidak Kami kisahkan tentang mereka kepadamu. dan Allah telah berbicara kepada Musa dengan langsung. (mereka kami utus) selaku rasul-rasul pembawa berita gembira dan pemberi peringatan agar supaya tidak ada alasan bagi manusia membantah Allah sesudah diutusnya rasul-rasul itu. dan adalah Allah Maha Perkasa lagi Maha Bijaksana. Dari rangkaian ayat- ayat tersebut, maka jelaslah bahwa menurut alQur'an, Islam adalah satu- satunya agama murni Samawi, sepanjang masa dan tempat.

\section{Kejahatan Atas nama Agama Islam}

Marl Juergensmeyer dalam buku yang diterjemahkan oleh Noorhaidi yang berjudul Menentang Negara Sekuler, sebagaimana dikutip oleh Endang, ${ }^{17}$ menyatakan bahwa Violence has always been endemic to religion. Images of destruction and death are envoked by some of religion's most popular symbols, and religious wars have left through history a trail of blood. The savage martyrdom of Hussain in Shiite Islam, the crucifixion of Jesus in Christianity, the sacrifice of Guru Tegh Bahadur in Sikhism, the bloody conquest in the Hebrew Bible, the terrible battles in the Hindu epics, and the religious wars attested to in Sinhalese Buddhist chronicles indicate that in virtually every tradition images of violence occupy as central a place as portrayals of nonviolence. Pernyataan tersebut seolah-oleh memaksa kita untuk percaya bahwa semua kekerasan atau kejahatan yang timbul tidak terlepas dari yang namanya agama.

Di Indonesia, agama Islam yang menjadi agama mayoritas penduduknya saat ini seperti menjadi pesakitan. Hal in disebabkan maraknya kasus kejahatan ataupun kekerasan yang dibalut dengan ajaran Islam. Sebenarnya, tidak hanya di Indonesia saja, di luar negeri juga sedang terjadi krisis kepercayaan terhadap pemeluk agama Islam yang disebabkan oleh kejadian-kejadian yang dilatarbelakangi oleh aksi ekstrimis dengan bendera Islam. Sudah banyak nyawa melayang dan kerugian yang disebabkan oleh kejahatan berkedok agama Islam.

Perlu disadari bahwa kejahatan berkedok agama tidak hanya dipicu oleh faktor eksternal seperti kepentingan politik, ekonomi dan sosial. Faktor internal juga dapat memberikan kontribusi yang besar. Masalah interpretasi atau penafsiran merupakan salah satu masalah utama yang bisa mendorong umat beragama melakukan tindak kekerasan.

Di dalam sejarah kekristenan banyak kejahatan yang dilakukan oleh gereja karena kesalahan dalam melakukan penafsiran terhadap Kitab Suci. Orang-orang yang tekstualis memahami apa yang tertulis di dalam Alkitab secara literal dan menerapkannya di dalam konteks yang berbeda. Proses eksegese yang sebenarnya diabaikan sehingga mereka gagal untuk

${ }^{17}$ H. Endang Saifuddin Anshari, M.A, Wawasan Islam...hlm. 69 
mendapatkan makna dari apa yang tertulis dan memusatkan perhatian terhadap teks secara mentah tanpa melakukan penggalian apapun.

Hal itu pun sama terjadi terhadap agama Islam, khususnya di Indonesia. Berdasarkan survei yang dilakukan, perilaku kejahatan agama di Indonesia berkorelasi positif dengan pemahaman agama yang tekstual. Ajaran-ajaran agama tentang kejahatan baik itu berasal dari Alqur'an, seperti kebolehan suami memukul istri bila ia mangkir dari kewajibannya (Q.S. 4: 3435), maupun Sunnah seperti hadis yang menyatakan anak perlu diperintahkan salat ketika berumur tujuh tahun, dan boleh dipukul (bila tidak salat) ketika berumur sepuluh, adalah sedikit contoh dari ajaran Islam tentang perlunya kekerasan.

Di Indonesia pada saat ini kita sedang berhadapan dengan gerakan Islam fundamentalis yang berusaha untuk mendirikan negara Islam. Sudah terbukti bahwa itu merupakan salah satu sumber terbesar kejahatan atas nama agama yang terjadi di negara kita. Bukan hanya gereja atau kelompok agama lain yang dianggap sebagai musuh melainkan juga kelompok Islam lainnya yang tidak setuju dengan ide negara Islam tersebut. Akibatnya negara kita mengalami penderitaan yang sangat dalam. Muncul kecurigaan antara pemeluk agama dan memicu terbentuknya semangat separatis.

Dalam realitas negara kita sekarang ini, terorisme adalah bentuk paling nyata dari kejahatan politik-agama di Indonesia. Dalam konteks teologis, terorisme bisa mengambil bentuknya dari agama sebagai landasan dan alat untuk mendapatkan kekuasaan, sebagai tujuan dari teror tersebut.

\section{Penipuan ala First Travel}

Baru- baru ini, masyarakat Indonesia dikejutkan oleh kasus penipuan yang dilakukan oleh perusahaan First Travel yang di miliki oleh designer pakaian ternama Anissa Hasibuan dan suaminya. First Travel merupakan perusahaan yang bergerak dibidang jasa penyedia perjalanan paket umrah yang murah dan telah memiliki ribuan konsumen.

Dari 74 ribu calon jemaah umrah, baru 30 ribu yang diberangkatkan oleh First Travel. Alhasil, uang lebih dari Rp 500 miliar menguap entah ke mana. Dalam sudut pandang kriminologi, kejadian ini dinamakan kejahatan white collar. Menurut Munir Fuady, white collar crime merupakan suatu perbuatan (atau tidak berbuat) dalam sekelompok kejahatan yang spesifik yang bertentangan dengan hukum pidana yang dilakukan oleh pihak profesional, baik oleh individu, organisasi atau sindikat kejahatan, ataupun dilakukan oleh badan hukum. ${ }^{18}$

Biasanya kejahatan tersebut sangat berkaitan dengan pekerjaannya sehari-hari, dengan tujuan untuk melindungi kepentingan bisnis atau kepentingan pribadi, atau untuk mendapatkan uang, harta benda, maupun jasa, atau kedudukan dan jabatan tertentu, perbuatan mana dilakukan oleh pelakunya bukan dengan cara-cara mengancam, merusak, atau memaksa secara fisik, melainkan dilakukan dengan cara-cara halus dan canggih, yakni dengan jalan menutup-nutupi, menipu, menyuap atau menerima suap, atau memainkan perhitungan akuntansi, yang biasanya (tetapi tidak selamanya) dilakukan oleh orang-orang yang mempunyai kedudukan tinggi dalam masyarakat dan mempunyai keahlian tertentu, dan biasanya pula perbuatan tersebut dilakukan ketika pelakunya sedang menjalankan tugas atau profesinya.

\footnotetext{
${ }^{18}$ Munir Fuady, Bisnis Kotor; Anatomi Kejahatan Kerah Putih, (Citra Aditya Bakti:Bandung, 2004), hlm. 311
} 
Di samping itu white collar crime memiliki ciri technology minded artinya mereka dalam menjalankan aksinya seringkali menggunakan modus-modus yang rumit dengan memakai alat teknologi canggih seperti komputer, telepon selular (misalnya lewat SMS), internet atau ecommerce sehingga tidak mudah terdeteksi oleh para penegak hukum dan hal itu jugalah yang menyebabkan manipulasi pasar semakin hari semakin meningkat jumlahnya. ${ }^{19}$

Dalam kasus First Travel, pelaku menggunakan harga murah dengan segala promosi yang ditawarkan. Harganya juga di bawah standar Kemenag. Mereka menggunakan jargon 'umrah dengan harga kaki lima fasilitas bintang lima'. Dengan harga yang murah, First Travel berhasil menarik minat masyarakat yang jumlahnya hingga ribuan. Dalam menjalankan kejahatannya, pelaku pada awalnya memang berhasil memberangkatkan sebagian konsumennya, sehingga mereka mampu meminimalisir kecurigaan masyarakat.

Dengan diberangkatkannya sebagian konsumen, maka konsumen yang lain merasa aman dan yakin mendaftarkan diri mereka untuk umrah. Namun, setelah sekian lama, baru masyarakat khususnya konsumen tahu bahwa uang yang telah diserahkan ternyata diselewengkan untuk kepentingan pribadi pemiliknya. Hal ini menimbulkan kemarahan masyarakat tidak hanya konsumennya tetapi seluruh masyarakat Indonesia. Kejadian ini semakin memberikan ruang untuk menyudutkan agama Islam sebagai sumber permasalahan. Agama Islam hanyalah sebuah alat untuk memanipulasi masyarakat demi keuntungan dan kepentingan pribadinya.

Penipuan berkedok agama Islam yang dilakukan oleh pemeluknya sendiri menyebabkan hancurnya reputasi Islam sebagai agama yang damai, agama yang rahmatan lil alamin, agama yang penuh rahmat dan kasih sayang. Agama Islam melarang keras setiap pemeluknya untuk melakukan kejahatan maupun penipuan.

Namun kejadian-kejadian tersebut membuktikan bahwa agama Islam yang dipakai sebagai formalitas, sebagai alat kejahatan. Mereka hanya memakai untuk mendapat keuntungan atau meraih kepentingan pribadinya, bukan subtansial. Padahal agama Islam bukanlah agama formalitas, ia harus dilaksanakan secara substansial, secara murni dan kaffah. Allah berfirman dalam surat Al-An'am ayat 160 yang artinya:

"Barangsiapa mengerjakan sesuatu kebajikan, maka (pembalasan) baginya sepuluh ganda kebajikan. Barang siapa melakukan kejahatan (kemaksiatan), maka tidak diberi pembalasan kecuali sesuai (seimbang) dengan apa yang dilakukannya. Mereka sedikitpun tidak dianiaya

(dizalimi)"

Allah juga berfirman dalam QS. Ash-Shuraa ayat 39

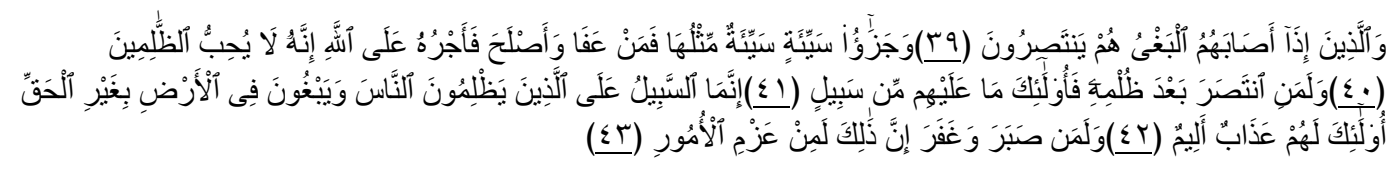

Artinya: dan (bagi) orang-orang yang apabila mereka diperlakukan dengan zalim, mereka membela diri. Dan balasan suatu kejahatan adalah kejahatan yang setimpal, tetapi barangsiapa memaafkan dan berbuat baik (kepada orang yang berbuat jahat)

${ }^{19}$ Munir Fuady, Bisnis Kotor...hlm. 313 
maka pahalanya dari Allah. Sungguh, Dia tidak menyukai orang-orang zalim. Tetapi orang-orang yang membela diri setelah dizalimi, tidak ada alasan untuk menyalahkan mereka. Sesungguhnya kesalahan hanya ada pada orang-orang yang berbuat zalim kepada manusia dan melampaui batas di bumi tanpa (mengindahkan) kebenaran. Mereka itu mendapat siksa yang pedih. Tetapi barangsiapa bersabar dan memaafkan, sungguh yang demikian itu termasuk perbuatan yang mulia.

QS. Hud ayat 18

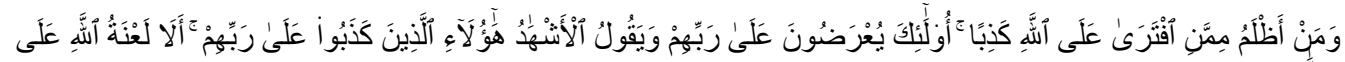

Artinya: "Dan siapakah yang lebih zalim daripada orang yang membuat-buat dusta terhadap Allah? Mereka itu akan dihadapkan kepada Tuhan mereka, dan para saksi akan berkata: "Orang-orang inilah yang telah berdusta terhadap Tuhan mereka". Ingatlah, kutukan Allah (ditimpakan) atas orang-orang yang zalim”.

Ayat-ayat tersebut di atas membuktikan bahwa kejahatan atau kezaliman tidak dibenarkan sama sekali oleh Allah Swt. Allah telah memberikan ancaman yang berupa neraka bagi pelaku kejahatan. Allah Swt juga menjanjikan syurga bagi orang-orang menjauhi sifat jahat dan akan memberikan pahala bagi orang-orang yang melakukan kebajikan.

\section{REFERENSI}

Departemen Pendidikan dan Kebudayaan. 1999. Penelitian Tindakan Kelas. Jakarta: Depdikbud.

A.S Alam. 1985. Kejahatan dan Sistem Pemidanan. Ujung Pandang: Fakultas Hukum, UNHAS.

A.S. Alam \& Amir Ilya. 2010. Pengantar Kriminologi. Makasar: Pustaka Refleksi.

Abdullah, M. Y. 2004. Studi Islam Kontemporer. Pekan Baru: Amzah.

Anshari, H. Endang Saifuddin, M.A. 2005. Wawasan Islam; Pokok-pokok pikiran tentang paradigma dan sistem Islam. Jakarta: Gema Insani Press.

Fuady, Munir. 2004. Bisnis Kotor; Anatomi Kejahatan Kerah Putih. Bandung:Citra Aditya Bakti

Nata, Abuddin. 2011. Metodologi Studi Islam. Jakarta: Raja Grafindo Persada.

Poerdarminta, WJS. 1982. Kamus Umum Bahasa Indonesia. Jakarta: Balai Pustaka.

Shodiq. 1988. Kamus Istilah Agama. Jakarta: Sienttarama.

Syahruddin. 2003. Kejahatan dalam Masyarakat dan Upaya Penanggulangannya. Fakultas Hukum Universitas Sumatera Utara. 